\title{
KEBUTUHAN KELUARGA SAAT ANAK DIRAWAT DI PAEDIATRIC INTENSIVE CARE UNIT (PICU): SUDUT PANDANG KELUARGA DAN PERAWAT
}

\author{
Efa Apriyanti ${ }^{*}$, Robiyatul Adawiyah \\ Faculty of Nursing Universitas Indonesia, Depok 16424, Indonesia \\ *E-mail: apriyanti.efa@ui.ac.id
}

\begin{abstract}
Abstrak
Studi literatur menyebutkan bahwa kebutuhan keluarga saat mendampingi anak dirawat di PICU sangatlah kompleks dan bersifat subjektif sehingga pengkajian kuesioner dirasa belum mampu mewakili gambaran kebutuhan keluarga yang sebenarnya. Tujuan dari penelitian ini adalah untuk membandingkan persepsi perawat PICU dengan keluarga pasien PICU mengenai prioritas kebutuhan keluarga dari anak yang dirawat di ruang rawat intensif. Penelitian ini menggunakan mixed method approach dengan pendekatan kuantitatif menggunakan desain cross sectional di tahap pertama pengumpulan data, dilanjutkan dengan pendekatan kualitatif yang dilakukan dengan cara wawancara mendalam di tahap ke dua. Data kuantitatif diperoleh dengan menggunakan Critical Care Family Need Inventory yang telah dimodifikasi. Hasil analisis data menunjukkan tidak adanya perbedaan yang signifikan antara persepsi perawat dan keluarga dalam menilai kebutuhan keluarga pasien PICU. Hasil ini menunjukkan bahwa secara umum perawat PICU di dua rumah sakit yang menjadi sampel dalam penelitian ini lebih mampu memahami kebutuhan keluarga pasien dibandingkan dengan perawat dalam penelitian-penelitian sebelumnya.
\end{abstract}

Kata Kunci: kebutuhan keluarga pasien PICU, mixed method, persepsi perawat

\begin{abstract}
Mutual understanding between nurses and patients' family on family needs during their child's stay in PICU. The literature review indicated that factors affecting parents' needs in a PICU are interrelated and not easily, or appropriately, assessed by using an inventory. Therefore, the objective of this study was to explore the needs of parents whose child has been an in-patient in a PICU, not only from the parents, but also from the perspective of nurses. A mixed method approach has been employed in this study. Quantitative data has been collected by using modified version of Critical Care Family Need Inventory, while the qualitative data was gained through in-depth interview. The result of data analysis showed that there were no significant differences between the perception of the nurses and parents regarding the needs. The finding suggests that in general, PICU nurses in these two hospitals have better understanding about the parents' needs in comparation with most of nurses in the previous studies.
\end{abstract}

Keywords: families' needs in PICU, mixed method, nurses' perception

\section{Pendahuluan}

Salah satu peristiwa yang dapat memberikan dampak sangat kuat kepada keluarga, terutama orang tua, yaitu ketika anak mereka harus menjalani perawatan di ruang rawat intensif. Beberapa penelitian telah mengidentifikasi bahwa masuknya seorang anak ke rumah sakit, khususnya pada Paediatric Intensive Care Unit
PICU), seringkali bersifat traumatik (Kinrade, Jackson, \& Tomnay, 2009), serta dapat menyebabkan distress fisik, psikososial, dan emosional, tidak hanya pada anak tetapi juga anggota keluarga lainnya (Shudy, et al., 2006; Smith, Hefley, \& Anand, 2007). Menurut Bronner, et al., (2010), satu pertiga dari orang tua pasien PICU memenuhi kriteria untuk dapat dikategorikan mengalami subklinikal Posttraumatic 
Stress Disorder (PTSD) dan 12,6\% dinyatakan secara klinis mengalami PTSD tiga bulan setelah anak mereka keluar dari PICU. Kinrade, et al. (2009) menjelaskan bahwa pengalaman psikologis dan emosional dari keluarga tersebut akan sangat bergantung pada seberapa besar kebutuhan mereka dapat dipenuhi oleh staf di ruang rawat intensif.

Perawat merupakan salah satu tenaga kesehatan yang dapat menjadi narasumber utama bagi keluarga pasien di ruang rawat intensif (Maxwell, Stuenkel, \& Saylor, 2007). Perawat ICU cenderung memiliki interaksi yang cukup dekat dan intens dengan keluarga pasien sehingga dinilai ideal untuk membantu keluarga pasien agar dapat berespon positif terhadap kondisi yang dihadapinya. Salah satu yang dapat dilakukan oleh perawat adalah membantu keluarga pasien agar dapat terpenuhi kebutuhannya selama anak menjalani perawatan di ruang rawat intensif. Untuk dapat menjalankan peran tersebut, perawat harus mampu memahami kebutuhan keluarga pasien sehingga pendampingan yang diberikan menjadi lebih efektif (Ames, Rennick, \& Baillargeon, 2011; Sargent, 2009). Dengan alasan tersebut, peneliti menilai bahwa perawat perlu memiliki kemampuan untuk dapat mengidentifikasi kebutuhan keluarga sehingga perawat dapat memberi asuhan keperawatan yang holistik kepada pasien dan keluarganya.

Penelitian yang bertujuan untuk mengidentifikasi kebutuhan keluarga dari pasien yang dirawat di ruang rawat intensif bukan merupakan hal yang baru, baik di ruang rawat intensif dewasa maupun anak. Setelah dimulai empat dekade yang lalu oleh Molter (1979), penelitian ini masih terus mendapat perhatian khusus dari para peneliti di berbagai negara, terutama negara maju (Al-Mutair, Plummer, Clerehan, \& O'Brien, 2014; Hinkle \& Fitzpatrick, 2011; Kinrade, et al., 2009; Mundy, 2010; Sargent, 2009). Sayangnya, penelitian terkait kebutuhan keluarga saat anak sedang dirawat di PICU baik dari sudut pandang keluarga atau perawat masih sangat sedikit di Indonesia. Peneliti juga belum menemukan artikel ilmiah yang dipublikasikan terkait dengan identifikasi kebutuhan keluarga dari pasien ruang rawat intensif anak. Oleh karena itu, dalam penelitian ini peneliti tertarik untuk mengidentifikasi kebutuhan keluarga dari anak yang menjalani perawatan di PICU, yang mungkin dipengaruhi latar belakang budaya yang berbeda-beda. Selain itu, penelitian ini berusaha untuk membandingkan prioritas kebutuhan tersebut berdasarkan persepsi keluarga dan perawat di PICU.

\section{Metode}

Penelitian ini menggunakan mixed method approach dengan desain sequential explanatory. Penelitian dilakukan di dua PICU di Provinsi DKI Jakarta. Sampel dalam penelitian ini adalah orang tua yang memiliki anak yang dirawat di PICU dan perawat di PICU. Kriteria inklusi untuk orang tua adalah ayah atau ibu yang telah menunggui anaknya di PICU lebih dari satu hari, berusia lebih dari 18 tahun, serta dapat membaca dan mengerti Bahasa Indonesia. Sedangkan kriteria inklusi untuk perawat adalah telah bekerja di PICU minimal 6 bulan saat penelitian dilakukan. Pengumpulan data terdiri dari dua tahap: 1) pendekatan kuantitatif dengan cross sectional, 2) pendekatan kualitatif dengan wawancara mendalam.

Pada tahap pertama peneliti melakukan survei deskriptif untuk mengidentifikasi dan membandingkan persepsi keluarga dan perawat tentang kebutuhan keluarga dari anak yang dirawat di PICU termasuk dengan prioritas kebutuhannya. Sampel pada tahap ini sebanyak 51 responden, terdiri dari 30 perawat PICU dan 21 keluarga pasien. Sampel diambil secara purposive sampling. Pada tahap ini peneliti menggunakan Critical Care Family Need Inventory (CCFNI) yang telah diadaptasi ke dalam Bahasa Indonesia dan telah disesuaikan dengan situasi, kondisi, dan budaya PICU yang ada di rumah sakit di Indonesia. Proses penerjemahan dan adaptasi instrumen telah dilakukan melalui konsultasi pakar dan back-translation. Untuk menguji validitas isi kuesioner, peneliti 
menyerahkan kuesioner tersebut kepada dua pakar yang terdiri dari perawat PICU dan perawat akademisi dengan kekhususan perawatan intensif pada anak. Selain itu, test-retest juga dilakukan guna menguji reliabilitas kuesioner yang telah dimodifikasi. CCFNI yang telah dimodifikasi terdiri dari 45 item pernyataan yang terbagi menjadi 5 subkategori, yaitu jaminan tentang hasil perawatan, kenyamanan, informasi, kedekatan, dan dukungan. Kuesioner ditampilkan dengan menggunakan skala Likert 1 untuk pernyataan yang dianggap tidak penting, sampai dengan 4 untuk pernyataan yang dianggap sangat penting. Selanjutnya pada tahap ke dua, peneliti melakukan wawancara mendalam pada 9 partisipan yang terdiri dari 7 orang tua pasien dan 2 perawat PICU untuk mengeksplorasi lebih dalam kebutuhan keluarga yang telah disampaikan sebelumnya melalui kuesioner. Penelitian ini dilakukan dengan memper-hatikan prinsip-prinsip etika penelitian dan telah mendapat izin etik oleh Komite Etik Fakultas Ilmu Keperawatan Universitas Indonesia.

\section{Hasil}

Tabel 1 dan 2 menggambarkan karakteristik partisipan. Adapun Tabel 3 menggambarkan tentang perbandingan prioritas kebutuhan keluarga pasien PICU berdasarkan subkategori pernyataan-pernyataan dalam $\mathrm{Critical}$ Care $\mathrm{Fa}$ mily Need Inventory (CCFNI).

Berdasarkan lima sub kategori dalam CCFNI, terdapat perbedaan yang signifikan pada sub kategori kebutuhan akan informasi, kedekatan dengan pasien, dan jaminan akan hasil dari perawatan $(\mathrm{p}<0,05)$. Terlepas dari perbedaan yang signifikan antara kedua kelompok dalam

Tabel 1. Distribusi Frekuensi Keluarga Pasien Menurut Jenis Kelamin, Tingkat Pendidikan, Penghasilan, Suku, Status Kepemilikan Asuransi Kesehatan, dan Hubungan dengan Pasien

\begin{tabular}{rcc}
\hline \multicolumn{1}{c}{ Karakteristik Keluarga } & $\mathrm{n}$ & Persentase (\%) \\
\hline Jenis Kelamin & 20 & 95,2 \\
a. Perempuan & 1 & 4,8 \\
b. Laki-laki & & \\
Tingkat Pendidikan & 3 & 14,3 \\
a. Dasar (SD-SMP) & 12 & 57,1 \\
b. Menengah & 6 & 28,6 \\
c. Tinggi & & \\
Penghasilan & 11 & 52,4 \\
a. Di bawah UMR & 10 & 47,6 \\
b. Di atas UMR & & \\
Suku & 3 & 14,3 \\
a. Betawi & 6 & 19,6 \\
b. Jawa & 4 & 38,1 \\
c. Sunda & 8 & 66,7 \\
d. Lainnya & & 33,3 \\
Status Kepemilikan Asuransi Kesehatan & 14 & \\
a. Memiliki & 7 & 90,5 \\
b. Tidak memiliki & & 4,75 \\
Hubungan dengan Pasien & 19 & 0 \\
a. Orang tua & 1 & 4,75 \\
b. Saudara Kandung & 0 & \\
c. Keluarga Besar & 1 & \\
d. Lain-lain & & \\
\hline
\end{tabular}


Tabel 2. Distribusi Frekuensi Menurut Jenis Kelamin, Tingkat Pendidikan, Usia, Suku, dan Lama Bekerja pada Kelompok Perawat

\begin{tabular}{rcc}
\hline \multicolumn{1}{c}{ Karakteristik Keluarga } & $\mathrm{n}$ & Persentase $(\%)$ \\
\hline Jenis Kelamin & & 100 \\
a. Perempuan & 30 & 0 \\
b. Laki-laki & 0 & \\
Tingkat Pendidikan & & 0 \\
a. SPK & 0 & 70 \\
b. D3 & 21 & 30 \\
c. S1 Ners & 9 & \\
Usia & & 6,7 \\
a. <30 tahun & 2 & 50 \\
b. 30-39 tahun & 15 & 36,6 \\
c. 40-50 tahun & 11 & 6,7 \\
d. >5 tahun & 2 & \\
Suku & & 6,7 \\
a. Betawi & 2 & 50,0 \\
b. Jawa & 15 & 13,3 \\
c. Sunda & 4 & 16,7 \\
d. Batak & 5 & 13,3 \\
e. Minang & 4 & \\
Lama Bekerja & & 26,7 \\
a. <5 tahun & 8 & 26,7 \\
b. 5-10 tahun & 8 & 23,3 \\
c. 11-20 tahun & 7 & 13,3 \\
d. 21-30 tahun & 4 & 10 \\
e. > 30 tahun & 3 & \\
\hline
\end{tabular}

Tabel 3. Perbandingan Prioritas Kebutuhan Keluarga Pasien PICU berdasarkan Subkategori CCFNI Menurut Kelompok Keluarga dan Perawat

\begin{tabular}{lccccccc}
\hline \multirow{2}{*}{ Subkategori } & \multicolumn{5}{c}{ Keluarga } & \multicolumn{3}{c}{ Perawat } & \multirow{2}{*}{$\mathrm{p}$} \\
\cline { 2 - 6 } $\begin{array}{l}\text { Jaminan tentang hasil } \\
\text { perawatan }\end{array}$ & Rerata* & SD & Min-Max & Rerata* & SD & Min-Max & \\
Informasi & 0,11 & $3,6-3,9$ & 3,55 & 0,17 & $3,2-3,7$ & 0,027 \\
Kedekatan & 3,54 & 0,25 & $3,2-3,8$ & 3,275 & 0,18 & $2,9-3,5$ & 0,035 \\
Kenyamanan & 3,37 & 0,29 & $2,8-3,6$ & 2,98 & 0,4 & $2,3-3,4$ & 0,034 \\
Dukungan & 3,14 & 0,45 & $2,7-3,7$ & 2,83 & 0,44 & $2,3-3,3$ & 0,214 \\
& 2,87 & 0,56 & $1,6-3,7$ & 2,87 & 0,58 & $1,5-3,8$ & 0,95 \\
\hline
\end{tabular}

* Rerata berdasarkan penilaian partisipan pada tiap pernyataan menggunakan skala Likert: $1=$ tidak penting, $2=$ agak penting, $3=$ penting, $4=$ sangat penting

menilai subkategori jaminan hasil perawatan, informasi, dan kedekatan dengan pasien, terdapat kesamaan urutan prioritas pada ketiga subkategori tersebut. Kelompok keluarga dan perawat memberi penilaian yang sama bahwa kebutuhan akan jaminan hasil perawatan, informasi, dan kedekatan dengan pasien merupakan 3 kebutuhan yang paling penting untuk 
dipenuhi. Hasil analisis data kuantitatif kemudian diperkaya dan divalidasi menggunakan tema-tema yang didapatkan melalui analisis data kualitatif.

\section{Kebutuhan akan Jaminan Hasil Perawatan.}

Selaras dengan hasil analisis data kuantitatif yang menempatkan kebutuhan akan jaminan hasil perawatan di posisi pertama, analisis data kualitatif juga menunjukkan hasil yang tidak jauh berbeda. Keluarga menilai bahwa jaminan anak menerima perawatan yang terbaik merupakan prioritas utama. Keluarga menyampaikan pentingnya dokter memberikan informasi secara berkala mengenai perkembangan anaknya dari waktu besuk satu ke waktu besuk berikutnya untuk memberikan assurance kepada mereka tentang hasil dari perawatan yang diterima oleh pasien.

"Kalau perlu kita (orang tua) mendapatkan penjelasan tentang kondisi anak kita di tiap waktu besuk, jadi kita bisa tahu ada perkembangan atau tidak dari waktu besuk satu ke waktu besuk berikutnya." (Partisipan B)

Orang tua juga menyampaikan betapa besar keinginan mereka untuk dapat mendapatkan informasi yang valid mengenai perkembangan anak mereka dari dokter penanggung jawab pasien untuk membuat mereka yakin dengan kondisi anak mereka.

"Kita pengennya disaat kita besuk itu dokter yang pegang dia itu ada disitu jadi kita pengen tau perkembangan anak kita gimana setiap harinya. Tapi kalau disini kan yang pegang itu ada yang dokter jaga ada yang perawat, kadang ada kadang engga, jadi kita mau nanya gitu ya sama dokter jaganya kalaupun ada dokter yang megang itu cuma sebentar itupun engga setiap hari, jadi kondisi anak yang kita pengen tahu cuma sebatas dari perawat sama dokter jaga tadi." (Partisipan F)

Kebutuhan akan Informasi. Analisis data kuantitatif menunjukkan bahwa kebutuhan ke- luarga akan informasi berada pada urutan kedua dan hasil ini didukung dengan jawaban kelompok keluarga dan perawat pada saat diwawancara. Kebutuhan keluarga akan informasi sangat jelas terlihat dalam hasil wawancara, dimana sebagian besar keluarga menyebutkan informasi sebagai salah satu kebutuhan prioritas yang sangat penting untuk dipenuhi. Selain informasi tentang perkembangan kondisi anak, keluarga juga membutuhkan informasi yang lebih spesifik seperti: informasi tentang penyakit dan pengobatan yang diterima oleh anak; informasi tentang tindakan yang dilakukan pada anak dan alat-alat yang terpasang pada anak, serta informasi tentang perawatan setelah keluar dari ruang rawat intensif. Meskipun orang tua meyakini bahwa dokter dan perawat lebih memahami segala tindakan yang dilakukan untuk menolong anak mereka, keluarga berharap tetap mendapatkan penjelasan, bahkan tanpa harus bertanya. Hal tersebut tergambar dalam hasil wawancara dengan partisipan berikut:

"Yang penting itu apapun tindakan untuk anak, kita diberi tahu, apapun kondisi anak kita sekarang, kita diberi tahu itu aja. Kalau semua obat-obatan kan dokter perawatnya (lebih paham), cuma kita pengen tau tindakan apa yang dilakukan, kalau sampai saat ini (informasi) itu sudah diberi tahu. Hanya untuk informasi kondisinya setiap hari itu tidak diberi tahu kalau kita tidak bertanya. Kita inginnya kan tanpa kita tanya, dokter dengan sendirinya manggil dan menjelaskan kondisi anak kita." (Partisipan F)

Kebutuhan akan Kedekatan dengan Pasien. Kebutuhan akan kedekatan dengan pasien menempati urutan ketiga dari lima subkategori yang ada dalam CCFNI, dengan rerata skor 3,37. Dimensi ini menunjukkan tentang bagaimana keluarga menilai keinginan mereka untuk dapat berada dekat dengan anak yang sedang sakit, baik secara fisik maupun emosi (Leske, 1991; Loghmani, Borhani, \& Abbaszadeh, 2014). Dengan tingginya jumlah rerata skor pada sub- 
kategori ini, maka dapat dikatakan bahwa sebagian besar keluarga ingin selalu berada dekat dengan anak yang sedang dirawat. Akan tetapi, hasil wawancara tidak sepenuhnya menunjukkan hal yang sama. Dua di antara sembilan partisipan menyatakan keinginannya untuk dapat lebih sering dan lebih lama bersama dengan anaknya, seperti tersirat dalam kutipan berikut:

"Jam besuk mulainya ya tepat lah, tapi kadang kita maklumin lah kalau (ada) tindakan (jadi) agak mundur gituh" (Partisipan D)

"Namanya kita (orang tua) (jenguk) setiap saat pasti maulah, supaya perkembangan anak itu lebih cepet yaa contohnya seperti anak saya kan penurunan kesadaran kalau penurunan kesadaran itu kan sebaiknya lebih sering kita rangsang dan lebih sering kita ajak ngobrol dan ketemu kan. Cuma kan kita mesti ngertiin juga kan peraturannya kan engga mungkin sebebas nanti mereka mau tindakan atau apa yang lain kan waktunya engga ada nanti, bagi saya sih engga masalah lah. Kalau bisa si dua jam lah, ini satu jam setengah kan. Kita si berharap cepet sembuh (pindah) ke ruang rawat biasa, jadi kita bisa full ya ngerawatnya. Jadi bisa jaga disampingnya, lebih bisa sering ajak ngobrolnya, atau kita stimulasi dengan pijat supaya anak lebih segar." (Partisipan A)

Sementara beberapa anggota keluarga tidak setuju apabila keluarga diizinkan membesuk kapan saja, seperti tertuang dalam kutipan berikut:

"Nah kalau jam besuk dibuat kapanpun kalau menurut saya juga engga bagus ya, di sini kan Ruang PICU itu namanya ruangan steril kalau sesering mungkin kita masuk itu namanya kita yang dari luar memasukkan kuman kan ke dalem, jadi dibatesin jam besuk kan jam segitu itu juga gapapa." (Partisipan E)

"Dibatasi (jam besuknya) tidak apa-apa biar anaknya istirahat." (Partisipan F)
Hal yang menarik adalah kedua partisipan yang menyatakan ketidaksetujuannya dengan jam besuk yang dibebaskan, yakni Partisipan E dan $\mathrm{F}$, menganggap kebutuhan akan kedekatan dengan pasien sebagai salah satu kebutuhan yang penting untuk dipenuhi saat mengisi CCFNI.

Kebutuhan Lain. Berdasarkan hasil wawancara, didapatkan beberapa kebutuhan yang juga dinilai penting oleh keluarga, namun tidak ada dalam CCFNI. Kebutuhan tersebut antara lain adanya tempat ibadah yang nyaman dan dekat dengan ruang tunggu, kamar mandi yang bersih, ruang tunggu yang terpisah antara laki-laki dan perempuan, bantuan biaya hidup atau transportasi untuk keluarga pasien, bantuan alat kesehatan yang diperlukan pasca perawatan PICU, serta pembatasan jumlah keluarga yang menginap di ruang tunggu. Dari keenam kebutuhan tersebut, empat diantaranya dapat dikelompokkan ke dalam kebutuhan akan kenyamanan dan 2 lainnya ke dalam kebutuhan akan dukungan.

\section{Pembahasan}

Penelitian ini bertujuan untuk mengidentifikasi kebutuhan keluarga pasien PICU melalui sudut pandang keluarga dan perawat PICU dengan menggunakan pendekatan mixed method. Hasil analisis data kuantitatif dalam penelitian ini menunjukkan bahwa dari 5 subkategori, 3 diantaranya menunjukkan perbedaan yang bermakna, yaitu kebutuhan akan informasi, kedekatan dengan pasien, serta jaminan akan hasil dari perawatan. Hal ini menunjukkan bahwa kedua kelompok memiliki rerata penilaian yang berbeda terhadap ketiga sub kategori, dimana kelompok perawat cenderung memiliki rerata penilaian kebutuhan lebih rendah dibandingkan kelompok keluarga. Terlepas dari perbedaan yang signifikan antara kedua kelompok dalam menilai subkategori jaminan hasil perawatan, informasi, dan kedekatan dengan pasien, terdapat kesamaan urutan prioritas pada ketiga subkategori tersebut. Kelompok keluarga dan perawat memiliki kesamaan dalam menilai prioritas kebutuhan untuk sub kategori jaminan hasil perawatan, informasi, dan kedekatan de- 
ngan pasien sebagai 3 kebutuhan yang paling penting untuk dipenuhi. Ketiga kebutuhan tersebut dinilai lebih prioritas dibandingdengan kebutuhan keluarga itu sendiri, seperti kebutuhan akan kenyamanan dan dukungan. Hasil ini berbeda dengan beberapa penelitian sebelumnya yang menunjukkan adanya perbedaan yang signifikan antara kelompok perawat dan keluarga pasien, tidak hanya dalam rerata penilaian, tetapi juga dalam menilai prioritas kebutuhan keluarga (Mi-kuen, French, \& Kaikwong, 1999; Ozbayir, Tasdemir, \& Ozseker, 2014). Hal ini menggambarkan adanya perubahan positif yang menunjukkan bahwa saat ini perawat sudah lebih mampu memahami kebutuhan yang dianggap prioritas oleh keluarga. Penilaian prioritas kebutuhan ini sesuai dengan penelitian oleh Yang (2008) dan Sargent (2009), baik pada keluarga pasien dewasa maupun pasien anak, yang menunjukkan bahwa jaminan tentang hasil perawatan, informasi, dan kedekatan dengan pasien merupakan tiga kebutuhan yang paling penting bagi keluarga pasien yang dirawat di ruang rawat intensif.

Kesamaan urutan prioritas ini juga dapat disebabkan oleh adanya kesamaan suku dari kelompok perawat dan keluarga pasien, dimana pada kedua kelompok sebagian besar partisipan berasal dari Suku Jawa. Sebagai salah satu negara yang terkenal dengan keanekaragaman budaya, ada lebih dari 300 suku di Indonesia, dan empat puluh dua persen dari total populasi Indonesia adalah Suku Jawa ((BPS), 2010). Salah satu karakteristik dari masyarakat Suku Jawa adalah hubungannya yang sangat dekat dengan kerabat dan tetangga, khususnya dalam memenuhi kebutuhan mereka akan dukungan (Zeitlin, 1995). Dalam penelitian ini, kelompok perawat dan keluarga pasien sepakat bahwa salah satu kebutuhan yang dinilai sebagai hal yang paling tidak penting untuk dipenuhi ialah "sendirian setiap saat". Pernyataan lainnya yang juga mendapat skor rerata cukup rendah adalah "memiliki tempat untuk menyendiri saat berada di rumah sakit". Penilaian terhadap pernyataan-pernyataan tersebut dapat menunjukkan bahwa di Indonesia, dengan mayoritas Su- ku Jawa, sebagian besar keluarga pasien yang menjalani perawatan intensif lebih membutuhkan dukungan orang lain dalam menghadapi masa-masa sulit daripada menghabiskan waktu sendirian.

Subkategori dukungan, sebagai satu-satunya subkategori dengan total rerata skor yang sama antara kelompok keluarga dan perawat, dinilai sebagai kebutuhan yang paling tidak penting. Rendahnya penilaian pada dimensi dukungan ini dapat disebabkan oleh belum tersedianya layanan dukungan khusus untuk keluarga yang anaknya dirawat di ruang rawat intensif di kedua rumah sakit yang dijadikan seting penelitian. Hal tersebut membuat keluarga belum pernah memiliki pengalaman tentang bagaimana support program dapat membantu mereka dalam menghadapi masa sulit selama menunggui anak di ruang rawat intensif. Selain itu, hasil ini mungkin juga dipengaruhi oleh adanya perbedaan bentuk dukungan yang dibutuhkan oleh keluarga, yang tidak tecantum dalam pilihan di CCFNI. Salah satu buktinya adalah keluarga menyebutkan dua kebutuhan yang termasuk dalam kategori dukungan ketika ditanyakan tentang kebutuhan lain yang penting untuk dipenuhi. Keluarga menilai pentingnya ada dukungan biaya hidup dan transportasi bagi keluarga serta bantuan alat kesehatan guna mendukung perawatan pasien setelah keluar PICU.

Kebutuhan lain yang juga dianggap tidak kalah penting adalah kebutuhan untuk bisa berada dekat dengan pasien, terbukti dengan terpilihnya kebutuhan ini ke dalam urutan ke tiga menurut kedua kelompok partisipan. Hasil ini tidak jauh berbeda dengan penelitian yang dilakukan oleh Sargent (2009) dan Mundy (2010) yang menunjukkan bahwa kebutuhan akan kedekatan dengan anak yang sedang dirawat di ruang rawat intensif merupakan prioritas kebutuhan yang penting untuk dipenuhi. Pada penelitian ini, kedua rumah sakit yang dijadikan seting penelitian memiliki aturan jam besuk yang cukup ketat. Keluarga memiliki jam khusus untuk menjenguk anak yang sedang di- 
rawat di ruang rawat intensif. Kebutuhan akan kedekatan masih mendapat skor yang cukup tinggi, hal ini dapat disebabkan oleh adanya aturan jam besuk yang masih belum banyak berubah jika dibandingkan dengan aturan jam besuk di ruang rawat intensif di negara maju beberapa tahun yang lalu, dimana keluarga hanya dapat menjenguk anaknya di waktu-waktu yang telah ditentukan. Akan tetapi, hasil ini tidak sepenuhnya sesuai dengan yang orang tua sampaikan saat wawancara dilakukan.

Melalui wawancara mendalam kepada beberapa orangtua pasien, didapatkan data bahwa sebagian orangtua menyatakan ketidaksetujuannya jika waktu besuk dibebaskan. Peneliti berasumsi bahwa perbedaan ini terjadi karena keluarga telah mendapatkan edukasi dari dokter ataupun perawat tentang alasan pemberlakuan jam besuk di PICU. Meskipun keluarga sangat ingin berada di dekat anak yang sedang dirawat, keluarga khawatir dengan risiko infeksi yang mungkin terjadi pada pasien jika keluarga sering berkunjung. Selain itu, ada juga keluarga yang merasa takut untuk berlamalama berada di dekat anak yang sakit karena dapat meningkatkan kecemasannya serta tidak tahu akan hal yang dapat mereka lakukan ketika berada di dekat anak yang sedang sakit.

Wawancara yang telah dilakukan juga memunculkan kebutuhan-kebutuhan lain yang dinilai penting oleh keluarga pasien, namun belum pernah muncul pada penelitian-penelitian sebelumnya. Beberapa keluarga pasien menyebutkan tentang kebutuhan-kebutuhan yang sedikit berbeda yang lebih lekat dengan budaya Indonesia, salah satunya yaitu kebutuhan akan tempat ibadah yang nyaman dan dekat dengan ruang tunggu. Kebutuhan akan ruang ibadah ini sangat bisa dipahami mengingat Indonesia merupakan negara dengan mayoritas penduduk beragama Islam yang memiliki kewajiban sholat lima waktu. Adanya ruang ibadah yang nyaman dan dekat dengan ruang tunggu, keluarga akan merasa lebih leluasa untuk sholat dan berdo'a di sana. Prinsip-prinsip agama merupakan sumber kekuatan yang penting bagi pasien dan keluarga dalam usaha meningkatkan kondisi kesehatan pasien (Loghmani, et al., 2014). Tindakan religius, seperti sholat 5 waktu bagi seorang muslim, merupakan suatu mekanisme yang lazim digunakan untuk meningkatkan harapan keluarga terhadap kesembuhan anaknya. Selain itu, tersedianya ruang ibadah yang nyaman dan mudah dijangkau dapat membuat keluarga yang tidak menjalankan ibadah sholat tidak akan terganggu ketika ada keluarga pasien menjalankan ibadah sholat di malam hari.

\section{Kesimpulan}

Penelitian ini menunjukkan bahwa kelompok perawat dan keluarga pasien memiliki kesamaan dalam menilai prioritas kebutuhan keluarga saat mendampingi anak di ruang rawat intensif untuk anak. Ketiga kebutuhan tersebut yaitu kebutuhan akan jaminan hasil perawatan, kebutuhan akan informasi, dan kebutuhan untuk selalu berada dekat dengan pasien. Kesamaan penilaian prioritas tersebut dapat dimungkinkan karena adanya kesamaan latar belakang budaya dari sebagian besar partisipan pada kedua kelompok. Hasil ini juga menunjukkan adanya perubahan ke arah positif dimana perawat sudah bisa menilai kebutuhan keluarga dengan lebih sesuai dibandingkan dengan hasilhasil penelitian sebelumnya. Kebutuhan lain yang teridentifikasi dari penelitian ini adalah kebutuhan akan tempat ibadah yang nyaman dan dekat dengan ruang perawatan anak serta beberapa kebutuhan yang dapat dikategorikan ke dalam kebutuhan akan dukungan dan kenyamanan (HY, NN, DW).

\section{Ucapan Terima Kasih}

Terima kasih penulis sampaikan kepada Fakultas Ilmu Keperawatan Universitas Indonesia yang telah memberikan Hibah Muda untuk mendukung pelaksanaan penelitian ini. Peneliti juga menyampaikan terima kasih kepada pihak-pihak yang telah membantu proses pengumpulan data di kedua rumah sakit yang menjadi sampel penelitian. 


\section{Referensi}

Badan Pusat Statistik (BPS). (2010). Kependudukan [Population]. Jakarta, Indonesia: Badan Pusat Statistik. Retrieved from http://www.bps.go.id/menutab.php? kat $=1 \&$ tabel $=1 \&$ id_subyek $=12$

Al-Mutair, A.S., Plummer, V., Clerehan, R., \& O'Brien, A.T. (2014). Families' needs of critical care Muslim patients in Saudi Arabia: A quantitative study. Nursing in Critical Care, 19 (4), 185-195. doi: 10.1111/nicc.12039

Ames, K.E., Rennick, J.E., \& Baillargeon, S. (2011). A qualitative interpretive study exploring parents' perception of the parental role in the paediatric intensive care unit. Intensive \& Critical Care Nursing, 27 (3), 143-150. doi: 10.1016/j.iccn.2011.03.004

Bronner, M.B., Peek, N., Knoester, H., Bos, A.P., Last, B.F., \& Grootenhuis, M.A. (2010). Course and predictors of posttraumatic stress disorder in parents after pediatric intensive care treatment of their child. Journal of Pediatric Psychology, 35 (9), 966-974. doi:10.1093/jpepsy/jsq004

Hinkle, J.L., \& Fitzpatrick, E. (2011). Needs of American relatives of intensive care patients: Perceptions of relatives, physicians and nurses. Intensive \& Critical Care Nursing, 27 (4), 218-225 218p. doi: 10.1016/j.iccn.2011.04.003

Kinrade, T., Jackson, A.C., \& Tomnay, J.E. (2009). The psychosocial needs of families during critical illness: Comparison of nurses' and family members' perspectives. Australian Journal of Advanced Nursing, 27 (1), 82-88.

Leske, J.S. (1991). Internal psychometric properties of the critical care family needs inventory. Heart Lung, 20 (3), 236-244.
Loghmani, L., Borhani, F., \& Abbaszadeh, A. (2014). Factors affecting the nursepatients' family communication in intensive care unit of Kerman: a Qualitative study. Journal of Caring Sciences, 3 (1), 67-82. doi:10.5681/jcs.2014.008

Maxwell, K.E., Stuenkel, D., \& Saylor, C. (2007). Needs of family members of critically ill patients: a comparison of nurse and family perceptions. Heart \& Lung, 36 (5), 367376.

Mi-kuen, T., French, P., \& Kai-kwong, L. (1999). The needs of the family of critically ill neurosurgical patients: A comparison of nurses' and family members' perceptions. Journal of Neuroscience Nursing, 31 (6), 348-356.

Molter, N. C. (1979). Needs of relatives of critically ill patients: A descriptive study. Heart \& Lung: The Journal Of Critical Care, 8 (2), 332-339.

Mundy, C.A. (2010). Assessment of family needs in neonatal intensive care units. American Journal of Critical Care: An Official Publication, American Association Of Critical-Care Nurses, 19 (2), 156-163. doi: 10.4037/ajec2010130

Ozbayir, T., Tasdemir, N., \& Ozseker, E. (2014). Intensive care unit family needs: Nurses' and families' perceptions. Eastern Journal of Medicine, 19 (3), 137-140.

Sargent, A.N. (2009). Predictors of needs in mothers with infants in the neonatal intensive care unit. Journal of Reproductive \& Infant Psychology, 27 (2), 195-205.

Shudy, M., de Almeida, M.L., Ly, S., Landon, C., Groft, S., Jenkins, T.L., \& Nicholson, C. E. (2006). Impact of pediatric critical illness and injury on families: a systematic literature review. Pediatrics, 118 Suppl 3, S203. 
Smith, A.B., Hefley, G.C., \& Anand, K.J.S. Zeitlin, M.J., Megawangi, R., Kramer, E.M., (2007). Parent bed spaces in the PICU: effect on parental stress. Pediatric nursing, $33(3), 215$.

Yang, S.P. (2008). A mixed methods study on the needs of Korean families in the intensive care unit. Australian Journal of Advanced Colletta, N.D., Babatunde, E.D., \& Garman, D. (1995). Strengthening the family: Implications for international development. Tokyo: UNU press. Retrieved from http://archive.unu.edu/unu press/unupbooks/uu13se/uu13se0a.htm. Nursing (Online), 25(4), 79-86. 